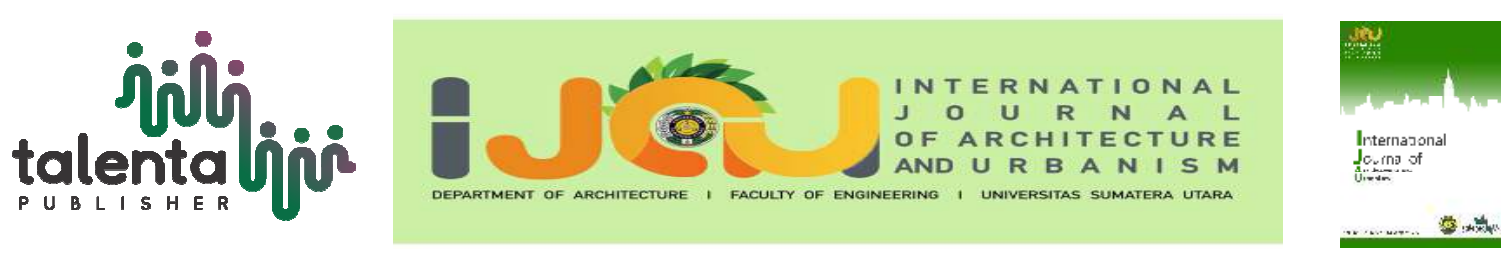

\title{
Preservation of Conclusion Temple with "Historic Urban landscape" Technique in the Universitas Islam Indonesia Environment
}

\author{
Rahmat Firdaus Bouty ${ }^{*}$, Arif Budi Sholihah ${ }^{1}$, Putu Ayu Pramanasari \\ Agustiananda
}

${ }^{1}$ Master of Architecture, Faculty of Engineering and Planning, Universitas Islam Indonesia, Indonesia

\begin{abstract}
Mataram civilization is a Hindu-Buddhist civilization. In the ancient Mataram kingdom, many buildings or artifacts were built for ceremonies such as the temple. One of them is Kecah Temple or Pustakala Temple located in the Indonesian Islamic University (UII). The temple itself was built by a group of people around who were relics in the 9th 10th century AD. This temple was discovered during the construction of the Library Building on December 9, 2009 which was then excavated by the Archaeological Heritage Preservation Hall (BP3K), in this temple there is a statue of God Ganesha which is interpreted as the god of intelligence and knowledge, which is very suitable for the Library Building gain knowledge. The existence of this temple is very guarded by the campus because UII is the only campus in Indonesia that has temples in the campus environment. However, this temple still lacks info about its original and historical name. The approach technique applied from the topic of "Urban Landscape Heritage" is the technique of preservation of Social Cohesion. In accordance with the definition of social cohesion, so that this building or temple can be maintained according to its function in the future, it is necessary to involve the opinions of visitors or respondents from the research. The research method used was observation and interviews of visitors to the library and the concluding temple museum to obtain statistical data and to study restoration techniques in the temple. The purpose of the study is to be able to find out information relating to the temple. Conclusion from the visitors about the concluding temple and review whether this temple is still suitable for use by Hindus as a ceremonial process or not. The results of the study can find a function of the Conclusion Temple which can be adapted to socio-cultural values so as to uphold tolerance of social values.
\end{abstract}

Keyword: kimpulan temple, library, universitas islam indonesia, preservation.

\section{Introduction}

The temple is one of the historical heritage buildings of the kingdoms in Indonesia. The temple of Conclusion itself is a proof of the past that is now in the village of conclusion right on the campus of the Indonesian Islamic University. This temple was named by the campus with the

*Corresponding author at: Master of Architecture, Faculty of Engineering and Planning, Universitas Islam

Indonesia, Indonesia

E-mail address: rfbouty@gmail.com. 
name Pustakala Temple which is in the sansakerta language, which means the library because it was found right at the time of the construction of the library building.

The discovery of this temple was accidentally discovered at the excavation of the building foundation column. The temple's findings are in the 16th column of 24 columns planned with a depth of $270 \mathrm{~cm}$ from the ground. After being found, UII immediately reported this discovery to the Archaeological Heritage Preservation Hall (BP3) in Yogyakarta, which then carried out excavation activities for further research.

The excavation is carried out in 3 stages, namely stage 1; December 12, 2009 - January 6, 2010, stage 2; 7 - 23 January 2010 and stage 3; dated 25-30 January 2010 [1] (Figure 1-4).

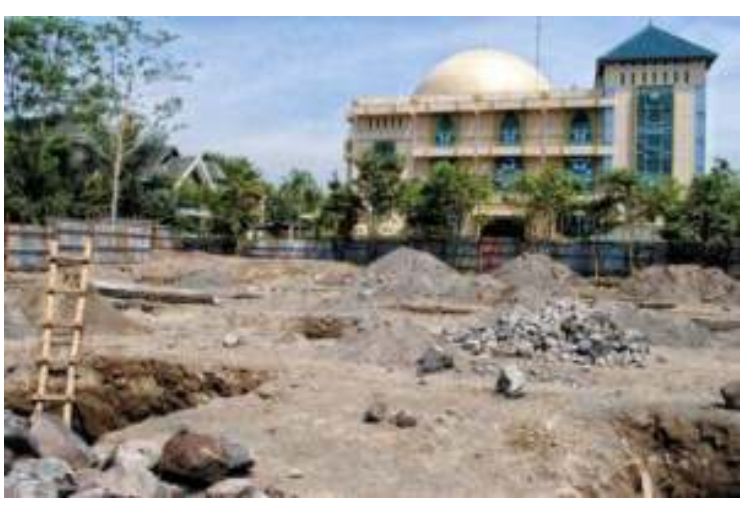

Figure 1. Excavation Stage

(Source: Kemendikbud, 2014 [2])

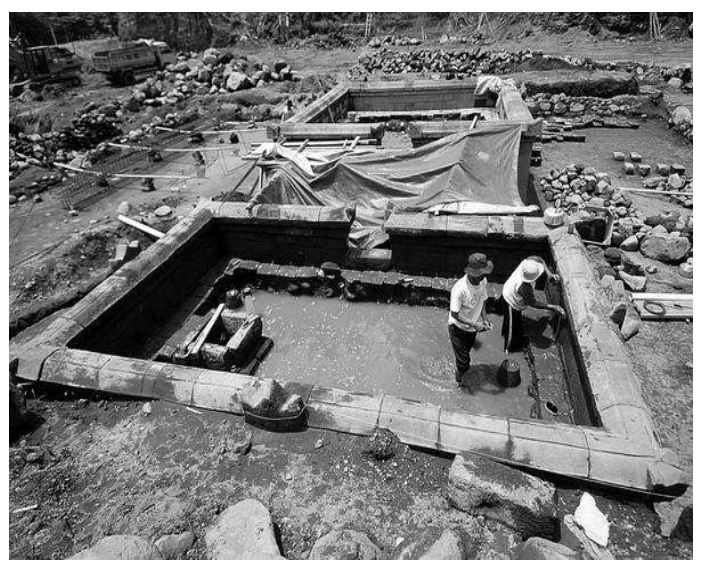

Figure 3. Excavation Stage

(Source: Kemendikbud, 2014 [2])

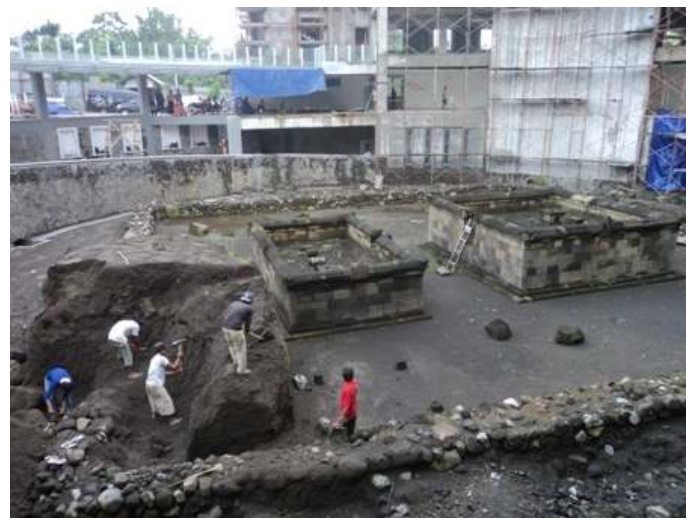

Figure 2. Excavation Stage (Source: Kemendikbud, 2014 [2])

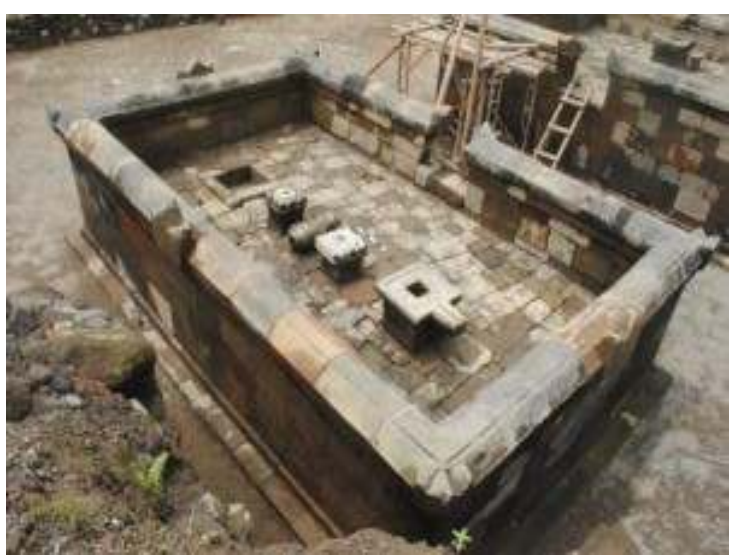

Figure 4. Excavation Stage

(Source: Kemendikbud, 2014 [2])

\section{Literature Review}

The temple comes from the word Candhika Grha which means the house of Dewi Candika. This candika goddess is interpreted as the god of durga death because the temple is used as a place of ceremony or worship to honor the kings who have died. The function of the temple is not always used by the kingdom but there are some parts of the temple used by the community which function as baths, arches, etc., [3]. For the concluding temple itself, the main function of 
the temple is still not found, while the understanding of archaeological researchers suggests that the conclusions were used as a place for reading the conclusion of the village itself.

The discovery of this temple changed the structure and architecture of the construction of the library building. According to [4] the library functions as a place of learning without differences in age, gender, ethnicity, race, religion and socio-economic status. So that the UII library can be used by all groups and is open to the public. History in the construction of a new library this time found the right temple with the library building in Indonesia.

The artifacts found in this concluding temple are the Ganesha Statue. According to [5] Ganesha is one of the Hindu Gods who is very well known as Lord Shiva and Dewa Parwati. In an interview with the author with Pak Maman as an archaeological researcher who is continuing his doctoral studies at UGM, he stated that the Ganesha Statue Artifact is very identical to the Elephant who was sitting with his trunk into a glass which was interpreted as being a science. This is very fitting with the construction of a library building adjacent to the discovery of the temple as a heritage of cultural heritage that cannot be found on other campuses (Figure 5).

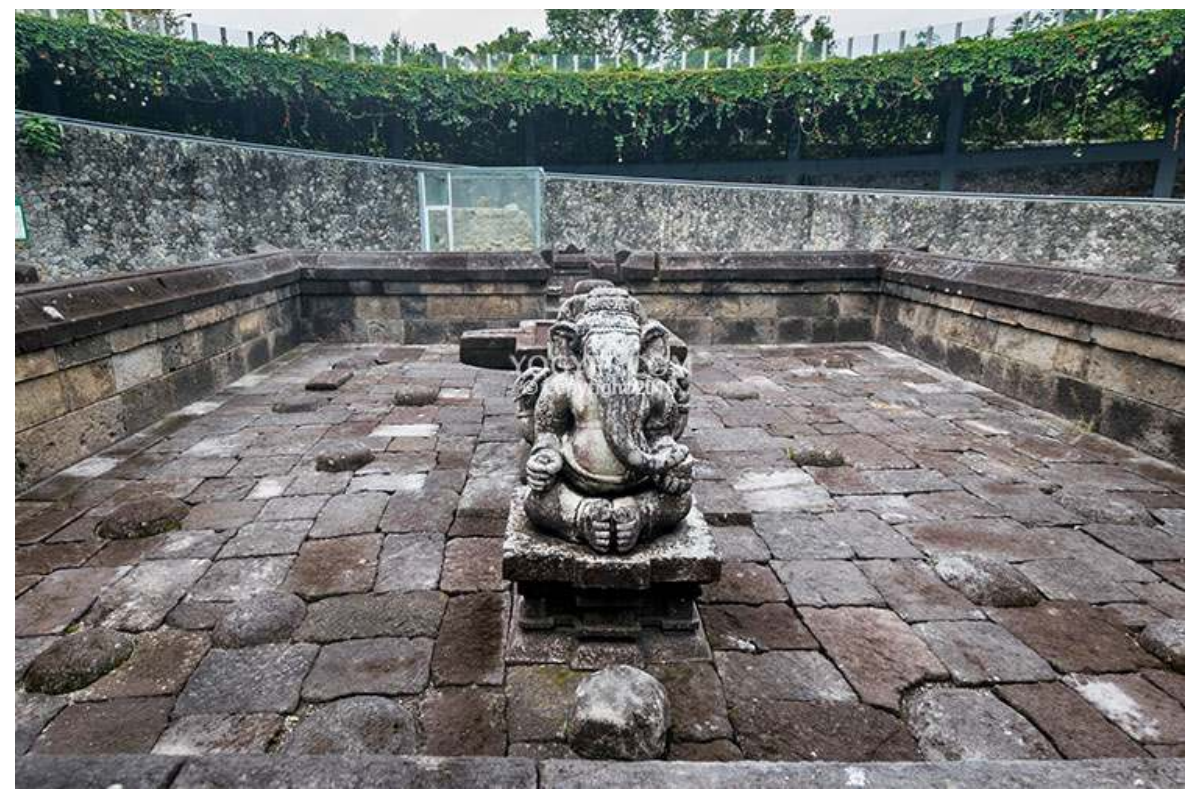

Figure 5. Arca Ganesha

(Source: https://www.yogyes.com/id/yogyakarta-tourism-object/candi/kimpulan/photogallery/5/.)

According to [7] when conducting a dissertation research in 1993, there are several sites or temples found in the Ngaglik District Sleman Regency, namely there are 8 sites. Five of them are in the village of Donoharjo, namely Ngepas, Jetis, maron, Temple, Candimendero and others scattered in the village of Sukoharjo, the Sembung site, in Sariharjo village, Randugowang and finally in the village of Sindurejo, Palgading. Where at that time there was no campus of the Indonesian Islamic University which found conclusions. 
According to some researchers in [8] a comparison of the inferred temples with other temples has been compared in terms of architecture, which shows that the overall architectural form of the temple cannot be known with certainty (Figure 6).

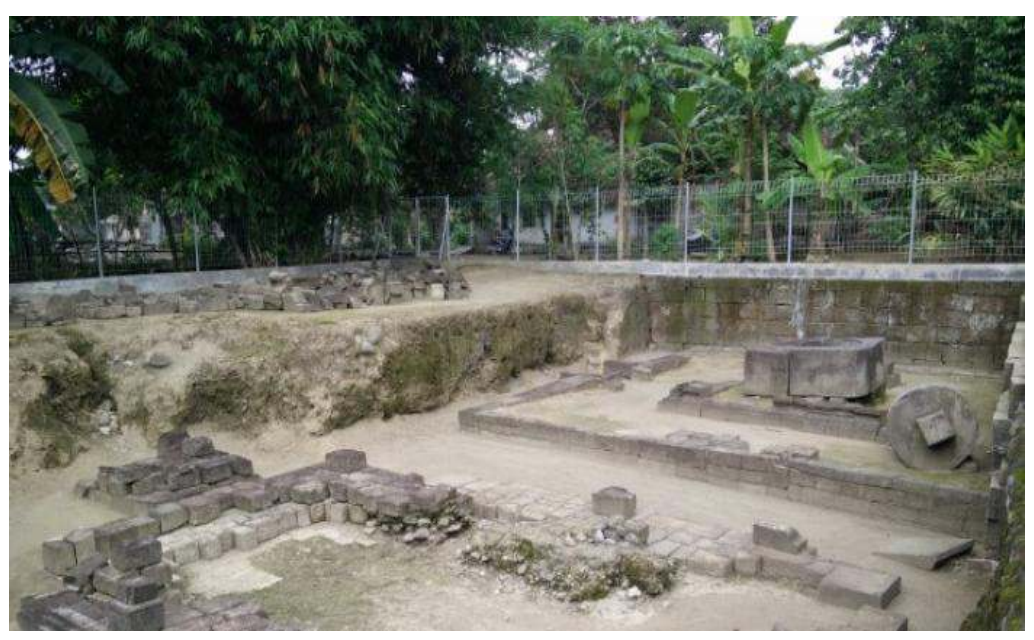

Figure 6. Palgading Temple

(Source: http://jogja.tribunnews.com/2016/01/05/candi-palgading-objek-wisata-sejarah-ditengah-desa-wisata)

On the Fusiontable website [10] no site or temple was found outside the city of Yogyakarta. If traced deeper with the guidelines from Mundarjito's research, many sites and temples have not been preserved, this is comparable with government regulations that require buildings or sites / temples to be at least 50 years old and will be given cultural heritage status [11]. This is inversely proportional to the preservation paradigm of Burra Charter where there is no minimum age requirement for a building or site to be categorized as cultural heritage [12].

\section{Methodology}

The approach techniques adopted from the topic "Historic Urban Landscape", namely the technique of preservation of Social Cohesion. The definition of social cohesion itself discusses how the past buildings were preserved in the present for future life as historical buildings and not only as museums or evidence but could be reused as their original designation such as ceremonies and offerings for Hindus [13].

The research method used is the observation and study of literature relating to preservation techniques and concluding temples. In HUL preservation techniques, there are very many methods that can be done namely: preservation, reconstruction, restoration, adaptive reuse, infill-design. In this study more leads to restoration, namely restoration techniques by not 
adding new material into the temple area. In terms of architectural, this temple has historical values and cultural values.

\section{Result and Discussion}

In accordance with [11], namely in article 77, the third paragraph is where restoration must allow for adjustments in the future while considering the safety of the community and the safety of cultural heritage. This is very consistent with the aim of the research related to how to maintain cultural heritage areas in the future. As well as in article II letter G where it reads preservation must consider "the principle of sustainability" that is the preservation of cultural preservation carried out continuously by considering the balance of ecological aspects.

From the research of Wahu Astuti in [8], he suggested a comparison of the differences and similarities of these inferred temples with other temples such as sambisari temples, gebang temples, boyolangu temples, upgrading temples and with the main temple yeh gangga temple.

a) Comparison with the sambisari temple, the similarity is that it can be found the same swear around the temple but it is blocked by the sambisari temple which is to have an intact temple building while the concluding temple is an open temple.

b) Comparison with Gebang and Klodangan temples, the equation is the location of the height of both buildings due to not having stairs on the temple. The difference is in the location of the ganesha statue, in the Gebang temple lying in a booth while in the concluding temple itself is located inside the temple.

c) Comparison with the boyolangu temple, the equation is from the same swear architectural form.

d) Comparison with upgrading temples, similarly, in terms of stone material as well as other temples.

e) Comparison with the main temple of Yeh Gangga building, the same is that the architectural form is very similar because it has an open roof.

Based on the results of the analysis from the literature review and questionnaires that have been carried out on the preservation of conclusions with social cohesion techniques, namely getting the answers that have been presented in percentages as follows: In accordance with the definition of social cohesion that this building or temple can be maintained according to its function in the future involvement of the opinions of visitors or respondents so that conclusions can be drawn on the best steps for restoration in order to survive until the future with the same function. 
In the preservation technique, it is necessary to have several system criteria such as spatial planning which explain how to use space in the temple and the surrounding space to function whether it is intended or not. The open space system, this system explains whether in this temple environment there is public or privacy so there must be certain conditions to see this concluding temple directly. Utilization system, this system is like a functional one where is this temple useful (Figure 7).

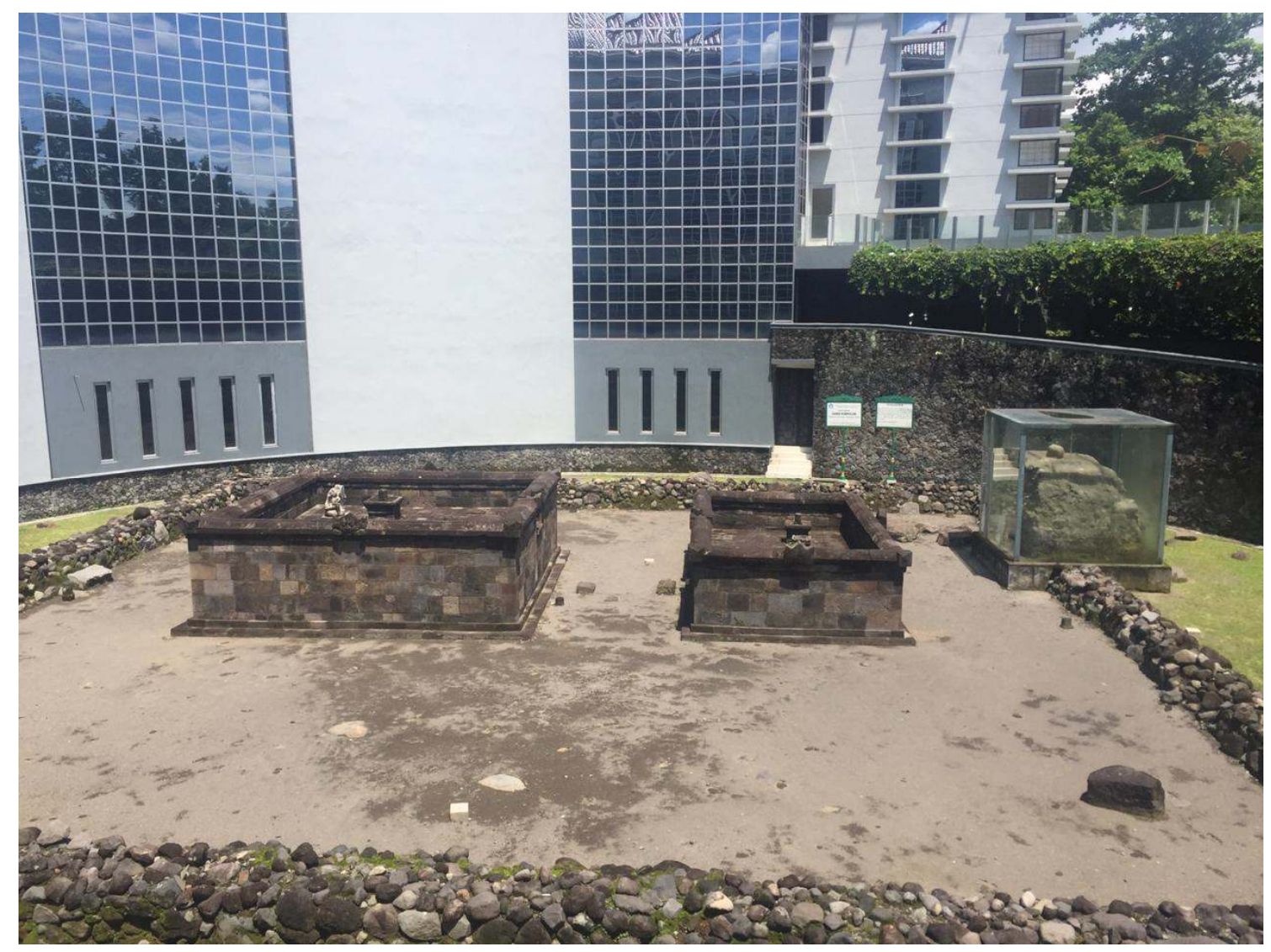

Figure 7. Kimpulan Temple

In this temple still does not maximize the initial function of the temple so that Hindu involvement is still needed to be able to discuss the initial functions of this temple. This concluding temple has a shape or role that is more than a temple that is adjacent to the concluding temple itself because this temple has very diverse artifacts.

This concluding temple requires the activeness of the students and the local community to be able to preserve this temple to face the future so that the generations can know the process of discovery and development of this concluding temple.

In the discussion of the author with archaeological observers, this temple has not been able to know the origin of the early history it was built so that more detailed research is still needed on this concluding temple. 
In the future, it is expected that the temple will still be closely guarded by the UII campus because there are many factors that cause damage to cultural heritage objects, namely natural factors and human factors. Natural factors are the decay of artifacts and objects found in the temple area while the human factors are sharply streaked, streaked streaks so that good guarding is needed. If not, then many lawsuits can be applied because this temple is a cultural preserve that needs to be preserved [14].

\section{Conclusion}

If it is concluded, the shape of the conclusions architecture is very much in need of preservation techniques because it can be used in the future.

This research is still in the implementation stage. The novelty of this study was to find out the preservation techniques of the inferred temple using the HUL "Historic urban Landscape" technique. In order to produce research that is suitable for the purpose, namely to be able to find out information relating to the temple, conclude from the visitors about the concluding temple and review whether this temple is still suitable for use by Hindus as a ceremonial process or not.

And the end of this research can determine the direction of preservation that fits the topic, namely the HUL technique in the social cohesion section. This research can be resumed by considering the regional sector which can be developed in terms of temple preservation.

\section{Acknowledgment}

Thank you to the Indonesian Islamic University Masters Study Program for providing opportunities and direction to the authors in the research writing.

\section{REFERENCES}

[1] R. W. Berman, Assesing Urban Design: Historical Ambience on The Waterfront., UK: Lexingtoon Books, 2006.

[2] D. S. a. L. Wilkes, "Understanding service-oriented architecture," The Architecture Journal, vol. 1, no. 1, pp. 10-17, 2004.

[3] A. A. a. M. N. I. I. a. T. P. See, "Sustainable Tourist Environment: Perception of International Women Travelers on Safety and Security in Kuala Lumpur," Procedia Social and Behavioral Science 168, pp. 123-133, 2015.

[4] A. Mendeley, Bibliography CSL_BIBLIOGRAPHY BP3 Yogyakarta, Media Komunikasi, Pemahaman Pelestarian \& Pemanfaatan BCB, Yogyakarta:Buletin Narashima, 2010.

[5] B. DIY, Candi Kimpulan, Yogyakarta: Kementerian pendidikan dan kebudayaan, 2014.

[6] D. A. Maryanto, Mengenal Candi, Yogyakarta: Univ. Negeri Yogyakarta, hal. 8-36,2007.

[7] A. S. Palupi, Landasan Konseptual Perencanaan dan Perancangan Perpustakaan Kota Di 
Yogyakarta, Yogyakarta: Univ. Atma Jaya Yogyakarta, hal. 18-42, 2012.

[8] A. G. B. A., Arca ganesa bertangan delapan belas di pura pingit melamba bunutin,kintamani, bangli, Balai Arkeol. Denpasar, hal. 25-34, 2015.

[9] J. T. Hartono, "Arca Ganesha di Candi Kimpula," [Online]. Available: https://www.yogyes.com/id/yogyakarta-tourism-object/candi/kimpulan/photo-gallery/5/.

[10] Mundarjito, Pertimbangan Ekologi Dalam Penempatan Situs Masa Hindu-Budha Di Daerah Yogyakarta : Kajian Arkeologi-Ruang Skala Makro, Universitas Indonesia, 1993.

[11] B. Yogyakarta, Prinsip pembangunan candi -Belajar dari kearifan lolal nenek moyang Pemugaran candi kimpulan -Keraton ratu boko, Yogyakarta: Buletin Narashima, 2011.

[12] Tribunjogja, "Candi Palgading, Objek Wisata Sejarah di Tengah Desa Wisata,' $\begin{array}{lllll}\text { TribunJogja.com, } & 05 & 01 & 2016 .\end{array}$ Available:http://jogja.tribunnews.com/2016/01/05/candi-palgading-objek-wisata sejarahdi-tengah-desa-wisata

[13] B. Yogyakarta, "Daftar Bangunan dan Situs Cagar Budaya Tingkat Kota Yogyakarta (2011)," 2011. [Online].Available:https://fusiontables.google.com/DataSource?docid=

1QhAoD1HTLgMiT_4a5EEgZZlv6GznaWBKaaklDBE\#rows:id=1. [Diakses 2013].

[14] Perpres, "Undang-Undang Republik Indonesia Nomor 11 Tahun 2010 Tentang Cagar Budaya," Indonesia, 2010, p. hal. 1-56. 